\title{
Conversion of Traditional Mythologemes in the Symphonic Music by Nikolai Mentser
}

\author{
Tatiana V. Leskova* \\ Khabarovsk State Institute of Culture \\ 112 Krasnorechenskaia Str., Khabarovsk, 680045, Russia
}

Received 17.01.2016, received in revised form 25.02.2016, accepted 19.04.2016

\begin{abstract}
The present article studies the combination of folk and original music from the point of view of conceptual interaction of the two artistic systems. The study is made from the specific theoretic and methodological angle of intertextual ideas typical for music by Nikolai Mentser, a composer who interpreted the folklore of the indigenous peoples of the Russian Far East in many diverse ways. The composer smoothly integrated this complex of concepts and styles into the system of academic genres of European composing professionalism. The presence of a distinctive plot and dramaturgy of his pieces is remarkable for the stability of patterns, images, and plots, researched by K.G. Jung on the basis of archaic mythology and mythologemes belonging to the class of archetypes. To reveal such mythologemes, a series of symphonies by N. Mentser with great generalizing potential is studied from the point of view of mythopoetics. In the plot and imagery of the music there is a cultural protagonist, the role which undergoes multiple transformations in modern mythmaking. Musical dramaturgy reveals the effect of general mythopoetic tendencies, such as binary opposition, and action-orientedness (normally harmonizing the initial situation) of the mythic-ritualness. These general rules are implemented in the music stylistics, the "folklore character" of which is achieved by means of folk tune quotations and free re-intonement of traditional music microstructures.
\end{abstract}

Keywords: composer folklorism, folklore re-intonement, mythopoetic archetype, indigenous ethnos of Russian Far East.

DOI: 10.17516/1997-1370-2016-9-6-1381-1390.

Research area: art history.

In Russian Neo-Folklorism of the late $20^{\text {th }}$ century and the Far Eastern composers' Folklorism as its regional version, the regional genesis prototypes served as an efficient impulse for creativity. In the Far East local indigenous folklore was best adopted in the context of European academic genres by Nikolai Nikolaevich Mentser (1910-1997)1. His work represented if not the whole folklore trend of the Far East of the 1960-80s, then at least its greatest part in the amount of created music, in the brightness, depth and diversity of the adopted folk genres.

The present article researches the interaction between traditional folklore and composers' work. We focus on the certain type of folklore prototype connected with the myths and rituals of the indigenous peoples of Russian Far East. The purpose of the present research is the analysis

(C) Siberian Federal University. All rights reserved

* Corresponding author E-mail address: leskova-1961@mail.ru 
of "re-intonement" of this prototype on the composition-dramaturgic, imagery-conceptual levels of symphonic music by N. Mentser.

Observing the imagery aspect of symphonic music, we find that in its plot $\mathrm{N}$. Metser implemented the "primary and the most stable patterns, images and plots of the folklore system", forming "a sort of its original fund" $[2,11]$. The system of such imagerydramaturgic archetype constants, demonstrated (first by K.G. Jung) on the basis of archaic myth-making, is conventionally referred to as archetypical mythologemes [2, 6]. Clarifying the tasks of the present article, let us emphasize the task of finding such mythological basics of plots, "underlying myth-like patterns" [4, 161], musical metaphors of the "collective" layer of dramaturgical contents and composition of the symphonic music by N. Mentser.

Myth and music, understood as texts (sign systems), interact both in the aspect of the information they bear and the ways used to code it. Being elements of a text "coming from outside" (in relation to the one written by the composer), the mythologemes have the property of intertextuality $[1,65]$ as they are adopted into the musical text written by the composer and into its components: meaning and structure [1, 32].

Mythopoetic intext of N. Mentser is manifested on two structural-conceptual levels. Firstly, it acts as a conceptual component, the plot which exists beyond the music, reflected in the internal content layer and the most general compositional features of imagery and plot system of the musical pieces. Secondly, it acts as a specifically "tangible" expression of this intext in music and style, as a musical, "folklore" thematic invention. Such thematic invention, created by a composer, previously existing as a phenomenon of the people's traditions, therefore bodies the traditional myth ritual on the levels of genre and intonement. The folklore intext of this aspect is found in the music by N. Mentser as quotes and such elements as smallest rhythm and intonation combinations, or microstructures. It is freely adopted by the composer (even in the first case of variation quotes) being an original author's work in its substance. Further we shall mostly analyse the first, imagery and conceptual kind of the mythopoetic intext, supporting it with the auxiliary analysis of stylistic peculiarities of the "folklore" musical thematic invention created by the composer.

N. Mentser's resorting to myth is determined with the dominating [6, 232], and, basically, emblematic position of myth-making in the folklore system of the indigenous peoples of the Far East. It is significant that, adopting their mythopoetics, the composer was guided by his own conclusions formed as a result of a systematic expedition research of the regional folklore he did in the 1950-80-s. The mythopoetic prototypes are adopted by the composer in a combination with the ethnographic ritual complex. It completes the used plot, thereby allowing us to refer to it as mythoritual, which is a wider term.

The myth systems are not presented in the works by N. Mentser as belonging to any ethnic classes (i.e. Chuckchee, Eskimo, Nanai, Ulch, Udege, Nivkh, Evenki etc.), though the titles often assume it; they are presented in a general way. It is determined, firstly, by the objective processes of assimilation occurring in the polyethnic regional folklore itself through the whole $20^{\text {th }}$ century, and, secondly, by the peculiarities of mythology as a universal sign system manifested in various plots with a common core $[4,248]$. At the same time, for example, on the conceptual-semantic level of the musical piece, in the correlation of the functional orientation of the myth and the common conceptual layer, the actual national "addresses" of such "plots" or the "program pattern" turn out to be irrelevant due to their great conceptual generalization. 
Myth-making and a composer's work are similar in many ways in the techniques of presenting reality, specific in the integrity of symbolism and chronicles. In the history of the Far Eastern composers' Folklorism, the creative method of N. Mentser turned out to be valuable due to the technique of artistic generalization ${ }^{2}$ of the life realia, representation of everyday life and local colours. The same is found and primarily generalized in a myth. But in the composer's works the chronicles are fuller and decorated with more details (despite the generalizing capacity of music). This peculiarity of the imagery system of the composer may have been formed with the mythosymbolics of the Amur peoples of the South of the Far East the composer was well familiar with. According to the existing observations, its specificity is determined with its proximity to reality and nature $[6,24]$.

Music pieces by N. Mentser ${ }^{3}$, seeming to be remote from traditional myths, shape their main archetypical image, i.e. the image of their forefather hero, who personifies the whole community and brings cultural and natural objects to people, creating the world for the people (creation myths). A relevant component of the hero mythologeme is struggling against a beast representing chaos. In this situation the hero personifies the cosmos [2, 18-20]. In some works by N. Mentser the hero archetype opposes the antihero archetype, a demonically negative or comic trickster.

The "relicts" of the forefather hero $[2,18]$ are presented in the works by N. Mentser with some peculiarities. In the archaic and newly developed mythology there is a difference between the creator hero and the bogatyr (knight) hero [2]. The context of the works by N. Mentser representing modern times makes it clear that the composer did not rely on the most archaic layer of mythology (though he was well familiar with the Raven cycle, which belongs to the archaic). In the symphonic poem
"The First Revcom of Chukotka" (1975) there acts the second type of the bogatyr hero (calling his people to struggle for the better tomorrow); at the end of the Symphonic Violin Concerto (1984) the generalized protagonist obtains the features of a powerful heroic personality with the interests merged with those of the people. In "National" symphoniette (1980) the four parts subsequently draw the plot line from the past to the present, representing the mythoritual side of the everyday life in a generalized way, too: "Songs of the Old Yaranga", "Dance of Joy", "Vanny-Yarara Tune" (also titled "Appeasement"); "Whose Reindeer Are the Fastest". It is remarkable that the past ("Songs of the Old Yaranga") is understood by the author as a narration, a brief memory pushed away with the contemporary life picture in the next part, "Dance of Joy", in the context of which the subsequent parts are also thought, as though under their own momentum, despite the traditional byplay.

In the mentioned musical pieces by N. Mentser the "collective" heroic "personality" type formed in the modern mythology of the $20^{\text {th }}$ century is mostly typical. Here we may speak of the specific "revision of hero archetype" [2, 33] and even of a substitution of the archetype in the composer's work. The mythoritual heroes in this music are not sacral mythic characters; those are workers and peasants: Soviet people and the ideal hero as a personified image of the Soviet person $[5,214-216]$. The newly created characters were also of mythological character.

For example, in the poem "The First Revcom of Chukotka" behind such image there is a revolutionary hero merged with the general public. Due to such typification, the composer creates a model of the people, which is abstract, but at the same time particular (which is typical of mythmaking as a whole) in its musical ethnic appearance and style. Such effect was achieved due to the properties of the 
written music. The mythmaking intentions are contained, on one hand, in the quotes of Russian revolutionary folklore ("Be Brave, Comrades, Keep Pace" etc.), and on the other hand, in the allusions of the indigenous peoples' music found in the pentatonic, trichord oligotonic scales. Other representatives of the traditional folklore semantics are the rhythmically aggravated motives, sophisticated melodic variation structures, reminding of the improvisational nature of folklore.

Behind this heterolexic [1] musical stylistics of the poem there is a myth-like generalizing concept, the "embryo" of the contemporary "celestial mythology" $[4,180]$ of the Soviet times idolizing the people's leaders, and in the given case the revolutionary heroes, Kulturträgers, calling for the new horizons. To keep the mythopoetic status of imagery, the composer preserved such properties of the hero mythologeme as his representativeness of the community (the whole Soviet people or a single ethnic community), creation of a new world/cosmos, struggle against the chaos. There is a paradoxical feature typical of the image of the "general hero" of this symphonic poem and other works by N. Mentser: modern characters live and act in the present times (the Soviet era), though connected with the mythic time ("pro-time" [4, 173]) and somehow continue living there.

The sense of statics, a specific "stability" and firmness of the conceptual system of $\mathrm{N}$. Mentser's music, the effect of multidimensionality (and probably mythical syncretism), their musical chronotopos are created by means of epic figural dramaturgy. The musical style of N. Mentser actively corresponds to the epic intext of Russian composing school of the $19^{\text {th }}$ century, and particularly with the symphonic music by A. Borodin, N. Rimsky-Korsakov. It may be the reason why music by N. Mentser bears the features of the general ideal concept of the "antiquity", semantically extrapolated to the contemporary time.

The image of a mythological mischief, rogue (the trickster) is not independently developed, but it contributes some universal comic carnival element into the music by N. Mentser. Abstract modelling of some sides of life, of the modern lifestyle as a harmonic, festive image of the indigenous people in the music may be found almost in all symphonic pieces by N. Mentser. In cyclic music genres (suites, symphoniettes, concertos) such imagery is, as a rule, extensively "depicted" in their final parts. We see them in the finals of the suites "The Nivkh Stories", "Chukotka-Eskimo", "Dance and Play", and symphoniettes "Youth" and "National". In the symphoniettes the same can be also said about their second parts: "Skerzo-Rondo" in the first and "Dance of Joy" in the latter. In the singlepart pieces such images are normally found in the final. It is illustrated in the "Evenki Rhapsody", "Chukotka-Eskimo Capriccio", "Northern Fantasy" etc. Characterizing the trickster and carnival element, we may remark its frequent connection to games, childhood and children's play, such as "Stick Fight" in "Dance and Play" suite.

Modern images of the trickster/enemy of the hero are based on the archetypical law, personified in the ethnocultural symbolic universum as a bourgeois, kulak, shaman, thief, idler, drunkard, which still does not deny mythologization found in the "universal" onesidedness of the negative evaluation of such social types. It is worth mentioning that this image component in its most concrete way was missing (or intentionally omitted) in the N. Mentser's sight, as contradicting the ideal mythomodel of the Soviet society. That is why in the symphonic music by N. Mentser there is no shaman mythoritual, as in the aesthetics of social realism the composer was probably devoted to 
the shaman was understood as a bearer of the "dark" past and the vestiges of the past ${ }^{4}$.

However, the composer does not at all avoid contrast and even negative images that symbolize the mythical chaos. They are mostly associated with natural phenomena, such as nasty weather, darkness, night, wind, or cold. They are found in the first parts of the symphoniettes: "Songs of the Old Yaranga" from "National" symphoniette, and "In The Kingdom of the Snow Queen" from "Youth" symphoniette, opening large-scale pictures of severe blizzard. The musical landscape of the stormy sea, anxiety of the women waiting for their fishermen husbands are depicted in the initial part of "The First Revcom of Chukotka" poem. Chaotic features are found in the scenes of struggle and death of the revolutionary hero for the sake of victory over chaos, achieving the new Soviet future in the second part of the poem titled "Despair".

The initial "bricks" of the mythological symbolic classifications are relations manifested in elementary semantic oppositions corresponding to the spatial and sensual orientation of a human (up/down), social relations (friend/foe) or on the edge of the society and the cosmos (water/ fire, home/forest), fundamental antinomies (life/ death, happiness/misery), as well as the main mythological opposition of the sacred and the mundane. Through the contrast of their sensual properties, the perception objects undergo the elementary analysis and classification in the mythology [4, 230-231]. A series of such motives finds its multilevel metaphoric semantic interpretation in the myth by means of hierarchic decomposition of the world into various levels/ codes. In mythopoetics they do not only exist separately, but can also be combined, and often they substitute the imagery meanings created before, serving as their synonyms.

Let us draw parallels between music by $\mathrm{N}$. Mentser and this side of mythological thinking. Thus, in some pieces the idea of bad weather is conveyed on several levels or in several codes. The multidimensionality of the imagery-associative sequence allows the listener to perceive the pictures of storm ("The First Revcom of Chukotka"), blizzard ("National" symphoniette) not only in the "meteorological" code (nasty weather), but also in the climatic (severe natures), "geographic" (North), "colour" (darkness), "tangible" (frost, cold), "temporal" (night), historical and chronological (past), and psychological (anxiety of the waiting women), "social" (suffering of the nation), "socially ranked" (simple poor people), fundamentally antinomic (death, loss of hunters). Having found the equivalence of these semantic codes, we may classify the codes opposite to them in their meaning as a different group: still air, soft climate, south, light, warmth, day, present, joy of reunion, joy of people, wealthy people, return of hunters. The cosmological understanding of the imagery structure of both musical pieces presents social categories through images from the natural environment and encodes natural relations in the social. It creates semantic correlations between different properties of the society and natural world, spoken "in the language" of different organs of senses. The associative flows can be reduced to the fundamental opposition of "disharmony/harmony". Inclusion of this opposition into a certain scale of values leads to the mental sacralisation, deification of the world of "harmony".

The said metaphorization of natural and social objects creates semantic paradigms in the imagery dramaturgy of both pieces mentioned above. The main collision occurs on the social level as a perversion of social justice. In the dramaturgy of "The First Revcom of Chukotka" poem this perversion is aggravated by the breathless expectation of the women, and in the dramaturgy of "National" symphoniette - by 
the failed hunting and the news of the hunters' death. The social perversion covers more than just "economy and trade" (fishing, hunting), but also other codes as well. Social and economic chaos is emphasized with disorder in nature and psychological disorders (motives of diffidence, agitation, suffering). On the opposite, the cosmic balance is supported with the economic wealth, joy of reunion ("The First Revcom of Chukotka"), successful hunting, victory in the reindeer racing ("National" symphoniette), “correct" social relations and general order.

This way the contents of the mentioned musical pieces as well as other works by $\mathrm{N}$. Mentser are mythologized, complete with multiple paradigmatic aspects of the imagery system. The main features of musical content mythologization are, firstly, the construction of mythological concepts as polyvalent symbols [4, 235], and secondly, the redundancy of codes (one and the same message is conveyed through several codes) $[4,234]$, and thirdly, simultaneous equivalence and hierarchic relations of the said codes [4, 245]. All this creates a multiple-level system, maximizing the imagery generalization of the musical content. Such symbolic classifications of the imagery, illustrated with the symphonic poem and the symphoniette, are generally universal for symphonic music by N. Mentser.

Thus, in a myth combination of equations (interlevel, "vertical") and oppositions (within a binary opposition, "horizontal") there is an essential structuring instrument. Due to the clearness of the "horizontal" binary oppositions, the "vertical" interlevel equations are laid into order.

The split-level "vertical" coding of images and their "horizontal" binariness are represented in the myth-like imagery systems and plots of Mentser's works. In these works, the "vertical and horizontal" imagery-mythological system finds a certain, but in a way metaphoric representation (through assimilation), which is achieved due to the peculiarities of the musical composition and dramaturgy. While the "vertical" construction of split-level codes has been given some attention, building "horizontal" myth-like imagery correlation requires some explanation.

An opposition significant for Mentser's "megatext" (symphonic music as a whole) is the opposition of "female-male". Female ceremonial dance had a specific magical meaning in the traditional lifestyle of the Far Eastern peoples; it was a symbol of fertility. In music by $\mathrm{N}$. Mentser the imagery of feminine dance lyricism constitutes the contents of certain pieces ("Female Dances of Chukotka", "Chukotka Dance", "Dance and Play" suite). But frequently the lyric imagery of this kind "interlays" the imagery dramaturgy of the suites ( $3^{\text {rd }}$ Part "Waltz" of "The Nivkh Stories" suite; $2^{\text {nd }}$ Part "The Konchelan Girls' Dance" of the "Three Orchestra Dances", "Dance of the Girl Named Vare" from "Chukotka Suite"), single-part pieces ( $2^{\text {nd }}$ part of "Chukotka-Eskimo Capriccio", $2^{\text {nd }}$ part of "Evenki Rhapsody", $2^{\text {nd }}$ part of "Fantasia on Amur Peoples' Folk Songs", $3^{\text {rd }}$ part of "The First Revcom of Chukotka" poem) or parts of cycles (intermediary part of "Dance of Joy" from "National" symphoniette). Having undergone the re-intonement process in the vocal and choreographic suites by N. Mentser written for amateur performance groups, traditional ceremonial dance music obtained some genre features of a waltz.

Demonstration of male competition games, an essential part of the hunting and fishing cult of the indigenous peoples, constitutes an imagery opposition to the dance lyricism of the suite cycles and single-part music (the first and the last parts of "Reindeer Racing" fantasia, final of "Whose Reindeer Are the Fastest" of "National" symphoniette, $3^{\text {rd }}$ part "The Stick Fight" of "Dance and Play Suite"). The images of game, rapid movement and joy are created 
through the diversely character of male dance with clear repeated rhythms (often resembling a march), fanfare-exclaiming character of musical intonations resembling well-rhythmed speech, massiveness of musical texture with enhanced role of drums etc.

Music by N. Mentser has developed some oppositions built on the "cyclic-wave" or "spiral" principle. Imagery repetition, cohering the musical composition or dramaturgy of the whole piece, correlates with the cyclic symbol mythologemes, i.e. happy return as repetition of the temporary death of nature for the sake of renovation in calendar myths, often personified in a dying and resurrecting god or hero [2, 11-14].

In this regard, "The Nivkh Stories" suite is especially remarkable in the way it depicts the everyday life pictures in its plot pattern. Its first part is titled "Return from Hunting", the second is "An Old Man's Story", the third is "Playing Kanga" and the fourth one is "Waltz". The suite parts are united with the principle of "general $\left({ }^{\text {st }}\right.$ part, A) - personified (two intermediary parts, B, C) - general (final, $\mathrm{A}_{1}$ ) - $\mathrm{ABCA}_{1}$. "Fantasia on the Amur Peoples' Folk Songs" is built on the imagery opposition principle of "male, soldierly-active, A - female, calm and lyric, B". The opposition acts within the framework of the $\mathrm{ABA}_{1}$ threepart composition, the last part of which, closing the imagery framework, is based on different musical and thematic material. Same type of compositional and dramaturgic "arrangement" is found in "Evenki Rhapsody". The imagery opposition of "the past, A - the present, B") is used in "The First Revcom of Chukotka" poem (A B A B A+coda $A_{1} A_{2} B_{1}$ ), where the lyric and dramatic imagery of A parts (based on the musical prototypes of indigenous folklore) contrasts with the epic and dramatic images of B parts (with the Russian revolutionary songs' prototypes).

Multiplication of dual oppositions of "pastpresent" is typical of "National" symphoniette. The images of the $1^{\text {st }}$ Part "Songs of the Old Yaranga", which begins with a vibrant landscape (A'), reminds of an agitated narration of the diseases beyond the human control and of the hunters driven away on a piece of ice torn away from the shore (A). It is opposed with the light (B), slightly sad $\left(\mathrm{B}_{1}\right)$ feminine lyric melody, a mirage picture of the ghostly return of the lost hunters $\left(\mathrm{B}_{2}\right)$. The lyric and dramatic character of the $1^{\text {st }}$ Part is opposed to the genre character of the other parts. Image contrast built on the principle of "male (A) - female (B)" is typical for the $2^{\text {nd }}$ Part "Dance of Joy", $3^{\text {rd }}$ Part "VannaYarara Tune" and plays the role of a slow lyric part (A), contrasting with the playful final "Whose Reindeer Are the Fastest" (B). The lower line of Figure 1 shows classification of images on the principle of generalized dual oppositions of "A - B". The middle line of the $1^{\text {st }}$ part shows the sequence of musical themes, the contents of which, despite the intonation individuality, are also built on the contrast principle, included into the binary imagery opposition principle common for the whole musical piece. At the end of the piece we find the enhancement of the image consolidation principle, which manifests itself in the larger imagery unity of the two last parts of the cycle.

The imagery "poles" create the compositional binariness of N. Mentser's music. The repeated

\begin{tabular}{|c|c|c|}
\hline Part I & Part II & Part III \\
\hline ntro $a b a c$ ad a $\operatorname{cod}$ & & \\
\hline $\mathrm{A}^{\prime} \mathrm{ABAB}_{1} \mathrm{AB}_{2} \mathrm{~A} \quad \mathrm{~A}^{\prime}$ & B A B & A \\
\hline
\end{tabular}

Figure 1. Classification of images in "National" Symphoniette 
comparison of identical images in the music dramaturgy reveals the inversion principle, which is also found in "National" symphoniette. Similar images come back, built on the new musical material, which creates the non-linear, inversionspiral-like compositional logic. Due to its formdeveloping potential in N. Mentser's music and in his cyclic music in particular, the contrasts, uniting the diverse elements into a single whole, look brighter and clearer.

A myth hero performs his feats in different places, trespassing different zones and penetrating into different worlds (the underground, the underwater, the land of the dead, the totem kingdom of his fiancée, the skies; after his miraculous adventures he may come back to earth). Other ways of narration are: adding episodes of finding (creating) different objects $[4,197]$ and going through different trials in initiation ceremonies. The archetypical travel pattern is the most elementary description of the world model $[2,50]$.

Such compositional specificity of the myth built on the principle of weaving and contrasting microcycles in the general narration structure may be correlated to the architectonic model of a cyclic musical piece, and, particularly, to the architectonics and dramaturgy of a suite so typical of N. Mentser's music. Almost all suites written by the composer are built on the contrastcomparison principle or the principle of contrastaddition of different "microworlds", or pictures of the people's life. Despite its relative imagery and conceptual completeness, the principle makes the imagery dramaturgy of the music more expositional. The principle of new music material introduction is compensated with the imagery binariness, concentrating into a single whole, as was described above.

Usually the general plot of the majority of the author's work is built on the dual image system "from darkness to light" (reminding of the capacious general principle of imagery dramaturgy of some works by L. Beethoven), and the similar functional orientation of the myth. It is based on overcoming the said mythlike fundamental antinomies in the struggle and the victory over chthonian powers, in bringing the world into order and harmony with human needs [2, 13-14], i.e. in ascending from chaos to cosmos. The protagonist acts as an intermediary who "resolves" the conflict and symbolically overcomes the binary opposition contrast.

One of the ways to represent the "game" through traditional archetypical antinomies in music by M. Mentser is the transition from "the past" to "the present", from "social chaos" to "social cosmos", from the "world creation" process to postulating it through the "universal celebration", from "disharmony" to "harmony". Such antinomies "stretch" from the beginning to the end of both single-part and many cyclic pieces, consolidating the suite composition of Mentser's "slices of life".

In the finals, reflecting the orientation of myths to reaching cosmos and reminding of massive festivals, the composer claims the value of the hero's deeds for his people. It is done through the ritual which is normally not shown, but implied through the universal celebration. The atmosphere of joy, cheerful reunion of people in a dance are associated with playful and ritual air of a carnival. The social polyfunctionality of the celebration is demonstrated by N. Mentser to its full. The "Massive national festivals" in the finals of his music perform multiple functions specific for a myth: the communicative, regulative (unity of the society, its new configuration and composition), emotional and psychological (statement of the joy of living), ideological, moral and educating, as well as firming the life renovation idea (new state of the society).

One of peculiarities of N. Mentser's myth interpretation is romanticization of mythoritual 
imagery. It is found both in resorting to folklore, using the archetypical motives in tight connection with the natural, everyday life, celebrating, ritual and historical backgrounds. Just like early Romanticists, the composer does not contrast the myth and history, trying to bring them together [4, 292]. In symphonic music by N. Mentser they are brought together through his resort to the present, which is the archaized but "living" history. It is idealized through creation of a harmonic model of the modern society of the indigenous Far Eastern Peoples, as modelling as one of specific functions of the myth $[4,170]$.
In this regard all works of the composer may be perceived as a single "author's monomyth" $[5,286]$. This system smoothly accepts the image of the composer himself, who integrated the Far Eastern folklore into European music genres, bringing the ethnic thereby to the general national scale. In the system N. Mentser's own mythologemes there is a light and harmonic imagery world, metaphorically created by the composer on the basis of the Far Eastern indigenous peoples' traditional folklore integrated into symphonic music.

$1 \quad$ N. Mentser (1910-1997) as a composer, was brought up in the academic traditions of professional European music. He set his main creative task as to revive the folklore of the Russian Far East indigenous peoples. The record archive he selflessly collected in expeditions and thorough research of the records, creation of over 30 symphonic pieces, around 50 arrangements of songs on folklore stylistic basis, organization of amateur and professional ensembles among the local population to reconstruct local musical folklore are very few of the results of his activity.

2 Generalized myth interpretation is determined by the youth of the Far East composers' organization first (experimental) resorts to folklore in local composers' music and in music by N. Mentser in particular.

3 Youth" overture (1937), "Hot Heart" poem (1942), four parts suite (1966), Khodze, the Negidal dance (1965), Katoka symphonic pictures (1965), "Seeing Sun", "Amur Fragments" fantasia (1966), "Seagull and Thunderbird" symphonic poem, "Female Dances of Chukotka", "Chukotka-Eskimo Capriccio", "Snow Queen", "Youth" symphoniettes, "He and She" fantasia, Fantasia on Two Chukotka Motives, "Northern Fantasia".

4 N. Mentser was determined about excluding shamanism from the imagery system of his symphonic music, though he composed a chamber piano piece titled "The Shaman Dance".

\section{References}

Aranovskiy, M.G. (1998) Muzykal'nyy tekst: Struktura i svoystva [Music Text: Structure and Properties], Moscow, Kompozitor Publ., 343 p.

Meletinskiy, E.M. (1994) O literaturnykh arkhetipakh [On Literary Archetypes], Moscow, Russian State Humanitarian University, 136 p.

Meletinskiy, E.M. (1979) Paleoaziatskiy mifologicheskiy epos: Tsikl Vorona [Paleoasian Mythological Epics: Raven Cycle], Moscow, Nauka, 230 p.

Meletinskiy, E.M. (2006) Poetika mifa [Myth Poetics], Moscow, Vost. lit., 407 p.

Skorinov, S. N. (2004) Mifologicheskaia kul'tura tunguso-man'chzhurov i nivkhov Nizhnego Amura i Sakhalina XIX $-X X v v$. [Mythological Culture of the Tungus-Manchu and Nivkhs of the Lower Amur and Sakhalin of the 19-20 $0^{\text {th }}$ centuries], Moscow - Khabarovsk, Moskovskiy gosudarstvennyy universitet kul'tury i iskusstv - Khabarovskiy gosudarstvennyy pedagogicheskiy universitet, $380 \mathrm{p}$.

Skorinov, S. N. (2004) Mifologiia i obriadovaia kul'tura nivkhov [Nivkh Mythology and Ritual Culture], Khabarovsk: Dal'nevost. gos. nauch. b-ka, 416 p. 


\section{Претворение традиционных мифологем \\ в симфонических произведениях Николая Менцера}

Т.В. Лескова

Хабаровский государственный институт культуры Россия, 680045, Хабаровск, ул. Краснореченская, 112

В данной статье сочетание фольклорного и композиторского рассмотрено $c$ позииий образно-кониептуального взаимодействия двух художественных систем. Особым теоретико-методологическим ракурсом при этом выступают идеи интертекстуальности, которая свойственна произведениям Николая Менцера, многообразно интерпретировавшего фольклор коренных этносов Дальнего Востока России. Композитору удалось органично интегрировать этот образно-стилевой комплекс в систему академических жанров европейского письменного профессионализма. Музыкальная программность, образная драматургия его произведений специфичны устойчивостью схем, образов и сюжетов, исследованных К. Г. Юнгом на примерах архаичного мифотворчества и принадлежащих к классу архетипических мифологем. Для их выявления ряд обладаюших большим обобщающим потенциалом симфонических произведений Н. Мениера рассматривается в аспекте мифопоэтики. В сюжетике и образности выявлена роль культурного героя, образ которого оказался подвержен трансформачиям в современном мифотворчестве. В музыкальной драматургии отмечено действие общих мифопоэтических закономерностей: бинарной оппозиционности, акичиональной (как правило, гармонизирующей исходную ситуаџию) направленности мифообрядности. Эти общие законы реализованы композитором в музыкальной стилистке, «фольклорность» которой достигается им в процессе иитирования напевов и свободного переинтонирования традиционных микроструктур.

Ключевые слова: композиторский фольклоризм, переинтонирование фольклора, мифопоэтический архетип, коренные этносы Дальнего Востока России.

Научная специальность: 17.00.00-искусствоведение. 